Polish Cartographical Review

Vol. 47, 2015, no. 3, pp. 147-158

DOI: $10.1515 /$ pcr-2015-0012

\author{
JACEK AUGUSTYNIAK, MARTA KUŹMA, PAWEŁ PĘDZICH \\ Faculty of Civil Engineering and Geodesy \\ Military University of Technology, Warsaw \\ jaugustyniak@wat.edu.pl,marta.kuzma@wat.edu.pl, ppedzich@wat.edu.pl
}

\title{
Review of the methods of cartographic presentation of warfare
}

\begin{abstract}
Maps, depicting the warfare, are elaborated according to the rules developed over the years. Although, they are not free of errors. The authors draw our attention to the diversity of methods related to the cartographic presentations, which are shown on the historical maps. This is quite understandable, because every such a map introduces an individual point of view on the historical facts. It is noted, that the most commonly used methods are the qualitative ones, among which, for instance, first of all, the method of signature is frequently used.

In the case of historical maps displaying an event in the specific sequence of times, a loss of cartographic information always occur. This is connected both with the complexity of historical facts and with the difficulty in reading a map, which should present the dynamics of this phenomenon in a complete way. The dynamic variables, such as the time of exposure, duration, frequency, order, degree of change and synchronisation, should be taken into account on the maps of warfare.

The use of information technology makes it possible to develop not only the simple maps presenting the course of warfare in the statistic and schematic ways, but also the maps, which are rich in various types of multimedia information.

Multimedia cartographic presentations can be enriched with the photos and panoramas showing the direct effects of warfare and the pseudo three-dimensional visualization showing the battle from a selected direction. The proprietary software let to combine the sequence of photos into a presentation, allowing to take a virtual tour of the areas directly affected by the hostilities. Network services, such as WMS, WFS, WCS, provide the integrated data from the different sources for us. So, we can connect the archival maps with the contemporary satellite images, defining, thus, the location of a specific place in the terrain.

The authors do not cover the issue of complexity connected with the elaboration of maps presenting the combat operations. The most important problems, which have not been discussed in this article, are the following ones: lack of base maps from the period to which the presented issues related, deliberate distortion of map contents, historical and cartographic imprecisions presented on the maps, appropriate selection of the methods of cartographic presentation related to the phenomena, which are presented on the maps.
\end{abstract}

Keywords: historical maps, military geography, cartographic presentation of warfare

\section{Introduction}

Military geography is mainly engaged into the studies of an impact of natural conditions on the hostilities, as well as into the spatial differentiation of these conditions. Space is one from the important elements for planning and caring out the military operations, as well as for their subsequent performance.

In the case of cartographic presentations related to the warfare time is the most important factor, which is conceived as the sequence of events and also as the measure of knowledge or access to it. Space and time are the objective factors, which should be the permanent reference plane for the historical presentations. These presentations are carried out mostly in the form of maps, depicting the distribution of objects and phenomena, their properties and interdependence. They do not engaged in the competition with each other nor in the text explanations, nor in the areas of aerial and satellite images, nor in the aspects of figures in the form of statistical tables (W. Grygorenko 1984). 
Therefore, an ability of reading the maps is very important. To understand a map you need to know the methods of cartographic presentation and to be able to find the relationships between the phenomena, as well as the impact of space and, not very rarely, the impact of time to these phenomena. W. Grygorenko (1984) calls this ability "a mental animation", which is essentially an ability of drawing the conclusions from our own observations combined with our own knowledge. This is particularly difficult, when we are dealing with the historical geography, which, unlike the geography of contemporary phenomena, explores the stages of their development, e.g., changes in the scope of occurrence of work tools, zones of political or cultural influences and also phases of actions of armed clashes (T. Rawski 1984). maps, but to show the possibilities of using the contemporary techniques to develop these kind of maps and, indeed, make them more attractive.

\section{Methods of presentation of warfare}

We often encounter a large variety of different cartographic methods, studying the historical maps. This is understandable, because every historical map shows an individual point of view on the historical facts. The most commonly known, qualitative methods are frequently used in cartography, including, in particular, the so called signature method, which shows a position of objects by signing the points or lines. The pictorial and symbolic signatures are mainly occurred on the historical maps. In the building

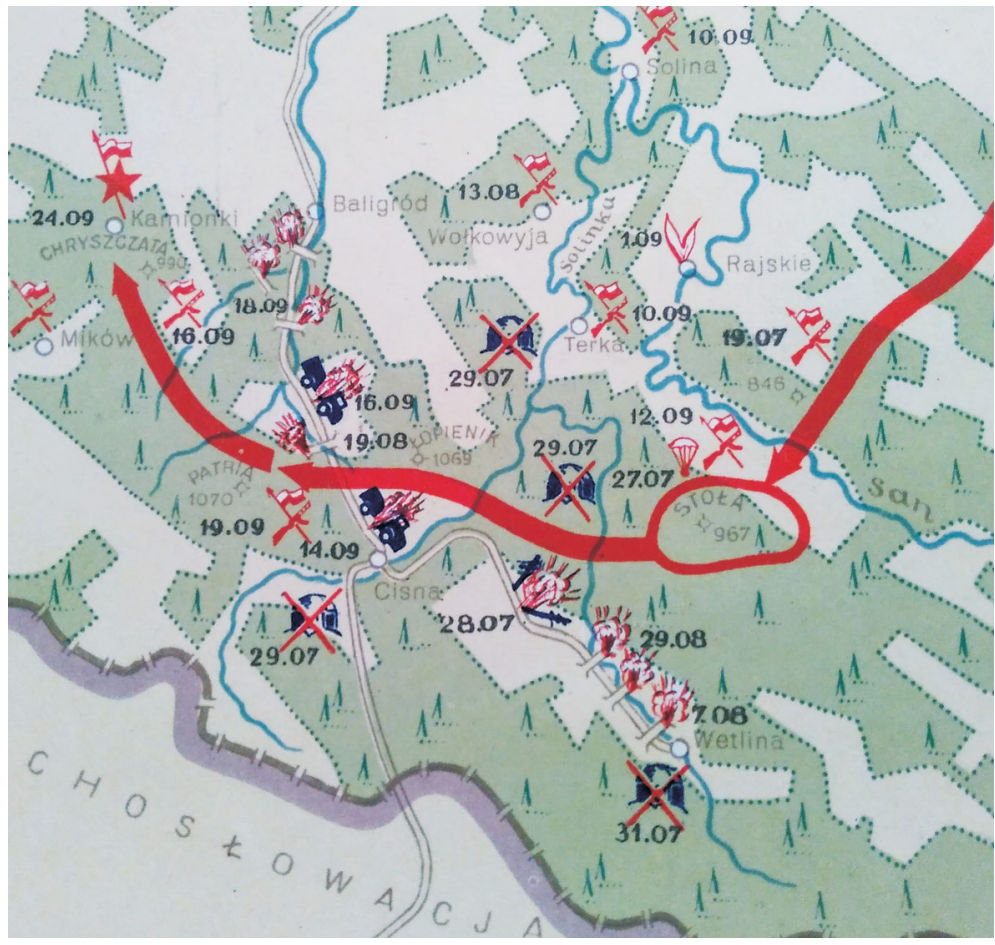

Fig. 1. Partisan fighting in the Carpathians (source: T. Rawski and others 1953) - the use of pictorial signatures

The basic problem connected with the elaboration of maps is the using of appropriate methods of cartographic presentation. The aim of the authors is not to evaluate the military of such signatures the combinations of geometrical and pictorial elements are used, so they can be easily identified (e.g. damaged car, line of communication, wrecked police sta- 
tion, skirmish, forester, church) (fig. 1 and 2). Recently, it is becoming increasingly popular to use the signs from the tactical and operational maps of NATO troops on the historical an image of relief, especially on the large-scale maps, is incomprehensible, because the descriptions of combat operations (both in fiction and in combat orders) contain the so

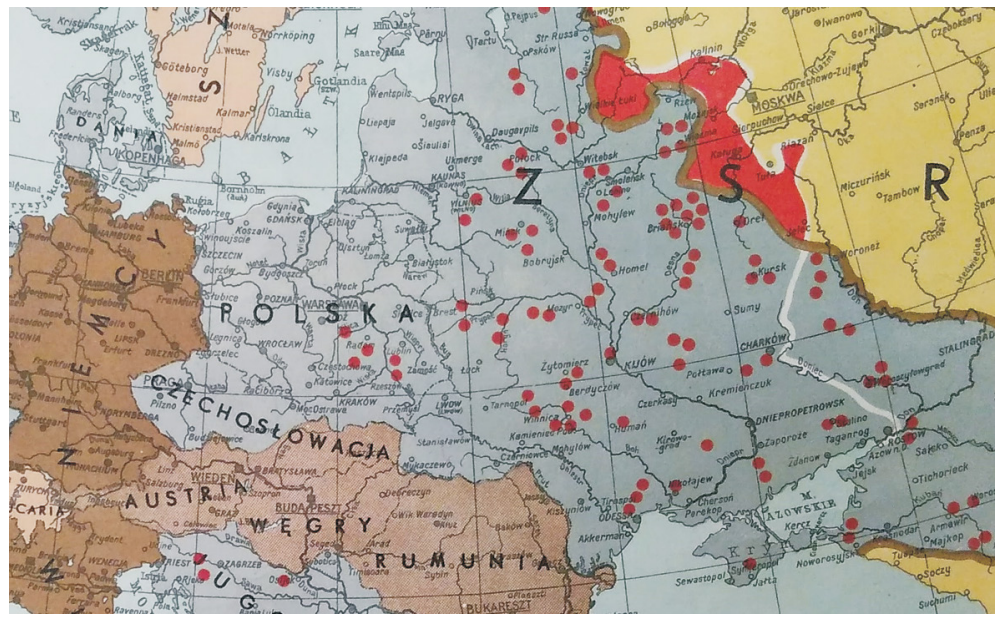

Fig. 2. The use of geometric signatures to perform the places of guerrillas' actions (source: The Second World War in Europe in 1941-1945, wall map, Nowa Era Publishing House)

maps. These are geometric signatures (fig. 3), but they do not seem to be appropriate to have a good application for historical maps, especially presenting the facts before the Second World War. Less frequently the letter signatures are used, and this is right, because they should not be used, while the meaning of abbreviations is not known well.

The linear signatures, which provide a wide range of possibilities for the qualitative and quantitative characterizations of object properties, are used very rarely. The method of linear signature can be used, for example, to show the front lines, as on the figure 4.

It should be noted, that the presentation of relief is often ignored by the authors of maps, unless it is a battle in a mountainous terrain, for instance, at Monte Cassino. It is understandable, that the hachures method is overlooked in the scope of these visualizations, because usually there are a lot of details on the military maps and a relief, presented by this method, would make it difficult to read the main content of a map. A better solution is to use the method of shading (fig. 5) or the hypsometric colourful layered method (fig. 6). In contrast, skipping

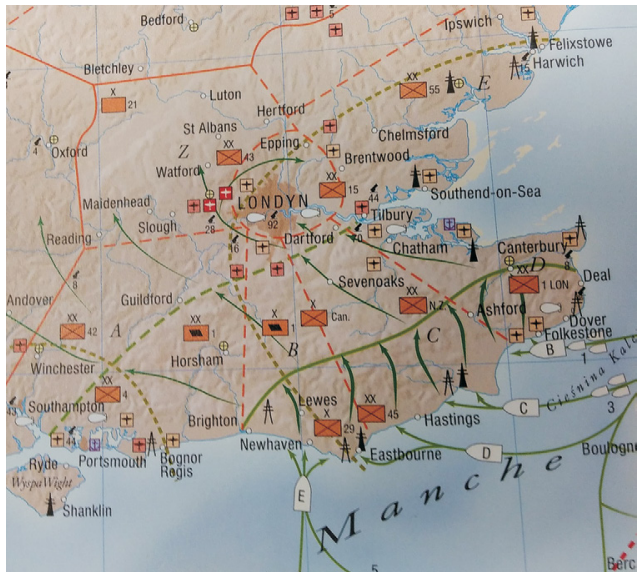

Fig. 3. The Battle of Britain - the use of geometric signatures as tactical characters (source: M. Swanston 2007)

called military analysis of a terrain to a varying extent.

The quantitative methods are also rarely used, that are cartodiagrams, choropleths, dot 
methods, isoline methods. The isoline method can be used yet, e.g., to mark on a map the areas of time accessibility (isochrones). It can also be used to show the areas, which are under the influence of combat units. Another example is the use of isoline to present the ranges of aircrafts, fighters, missiles, artillery, etc., in the form of circle or concentric circles, the centre

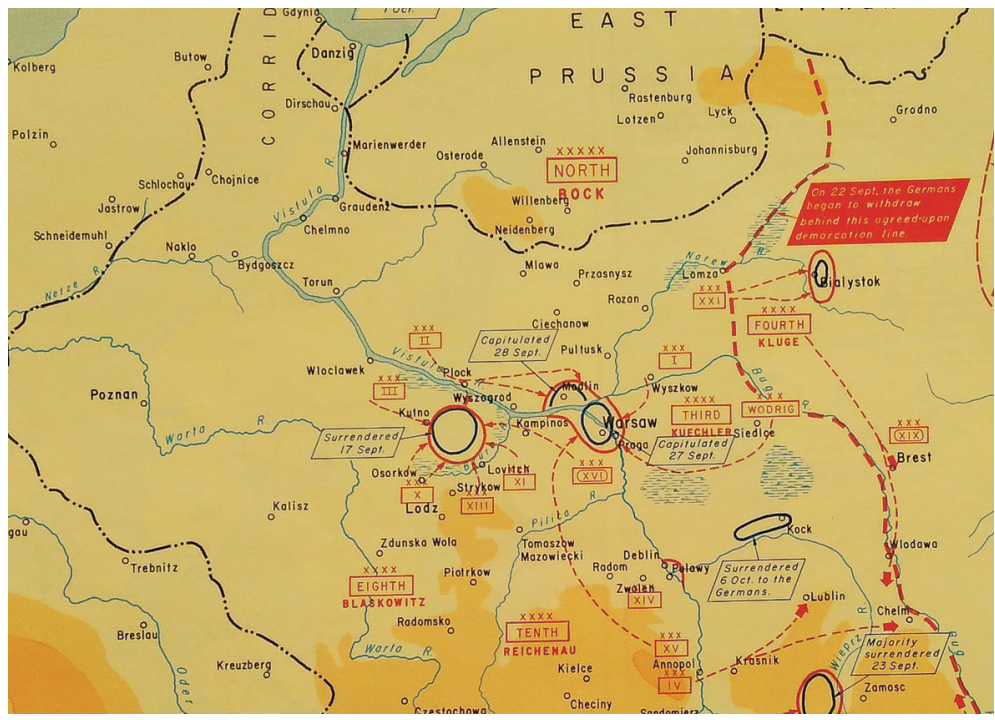

Fig. 4. The military campaign in Poland in 1939 (source: T.E. Griess 1987)

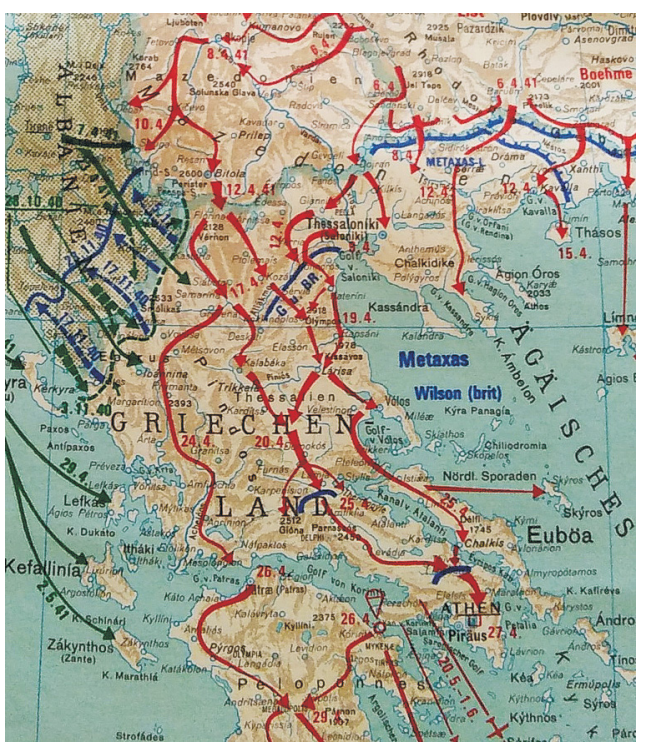

Fig. 5. Hostilities in Greece in 1941 - an example of a map on which the relief is represented by shading (source: E. Tschudi 1964) of which is the location of perpetrators of the attack (fig. 7).

By using a cartodiagram we present the quantitative characteristics of phenomena and the facts in their mutual relations connected with the position (L. Ratajski 1989), so, for example, with the help of cartodiagram related to simple points we can show the size of the losses suffered during the war. The cross on the figure 8 symbolizes the number of killed in three classes - more than 1000, 100-1000 and less than 100 people.

The use of certain cartographic methods results in the lack of historical and cartographic precision, which is caused by the lack of up-to-date base maps or the lack of full historical description of a certain fact. It may also be the result of external censorship or any incorrect self-censorship, as well as the mismatches of method to this content.

During the process connected with the elaboration of map one should remember to use the principles of syntactic and pragmatic approaches. It also means that a cartographer should work 
closely in a cooperation with a historian. Such cooperation, which, unfortunately, very often is rather difficult, should lead to both accurate historical facts and the accuracy of cartographic presentation. It should not, therefore, be found the non-existent at that time towns, bridges, roads, railways, forests, etc. on the map for

\section{The application of geoinformation technologies for the elaboration of maps of warfare}

Geoinformation technologies allow us to elaborate the maps in a digital form, using the spatial databases containing the geometric

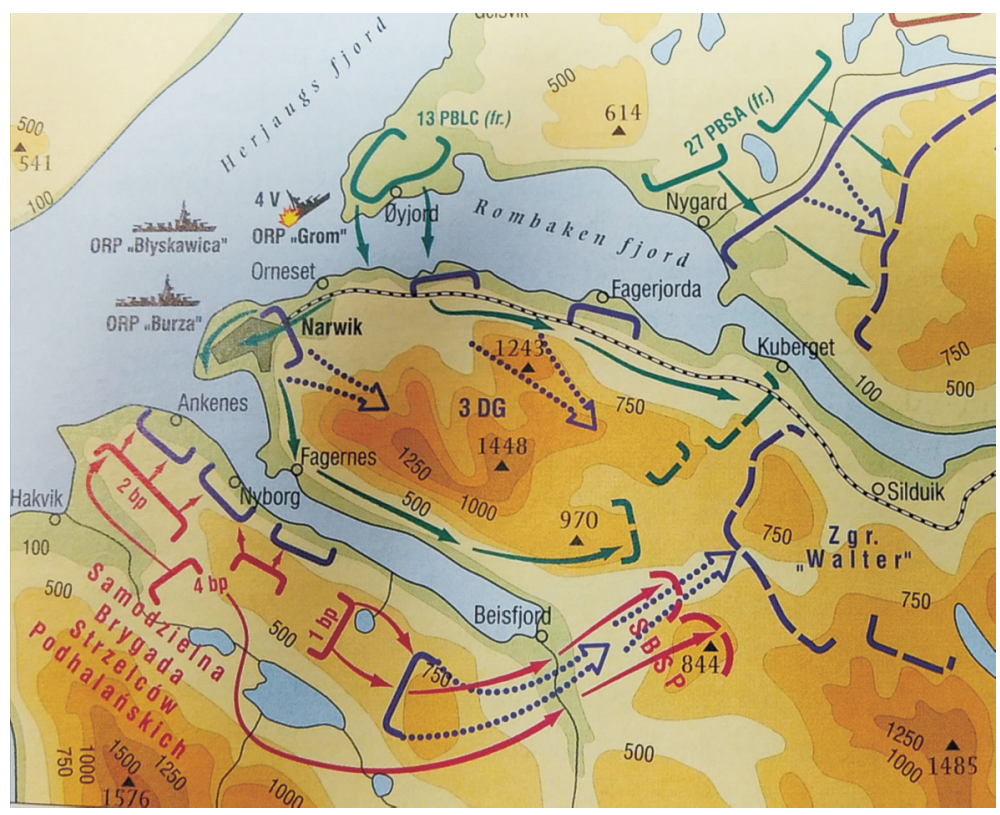

Fig. 6. The Battle of Norwich - the use of the hypsometric method to present a relief (source: E. Olczak 2004)

a specific period of time. There should not be presented also the villages that have been omitted by certain combat operations.

A classic mistake is the using of too broad arrows of motion (a vector diagram) presenting the directions of warfare (fig. 9 and 10). Their direction, width and colour carry the specific information, and their appropriate placement results in the correct presentation of historical facts. On elaboration of military maps, the scale of map is of the great importance, which affects the use of proper methods of cartographic presentation. We should also be aware of unified generalization of thematic and base map contents. The lack of "synchronization" of these contented layers can cause the incomplete transmission of information intended.

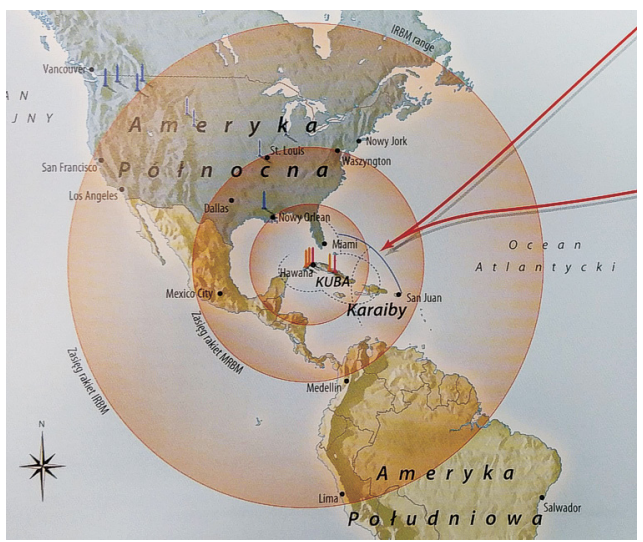

Fig. 7. Cuban missile crisis - an example of a map which the equidistant method present the range of missiles is used (source: A. Swanston, M. Swanston 2011) 
data together with the descriptive ones. These data can be related to the multi-media data, obtaining thus very attractive cartographic elaborations. Our modern geoinformation technologies also allow us for the rapid data publication on Internet and connection the data from different sources with the help of a Web service.
Moreover, they also allow us to display the maps, using different mobile devices, and interact with them in a terrain.

These very interesting possibilities can be used to develop the military maps, creating the mobile guidebooks of places affected by the battles, using the so-called augmented reality,

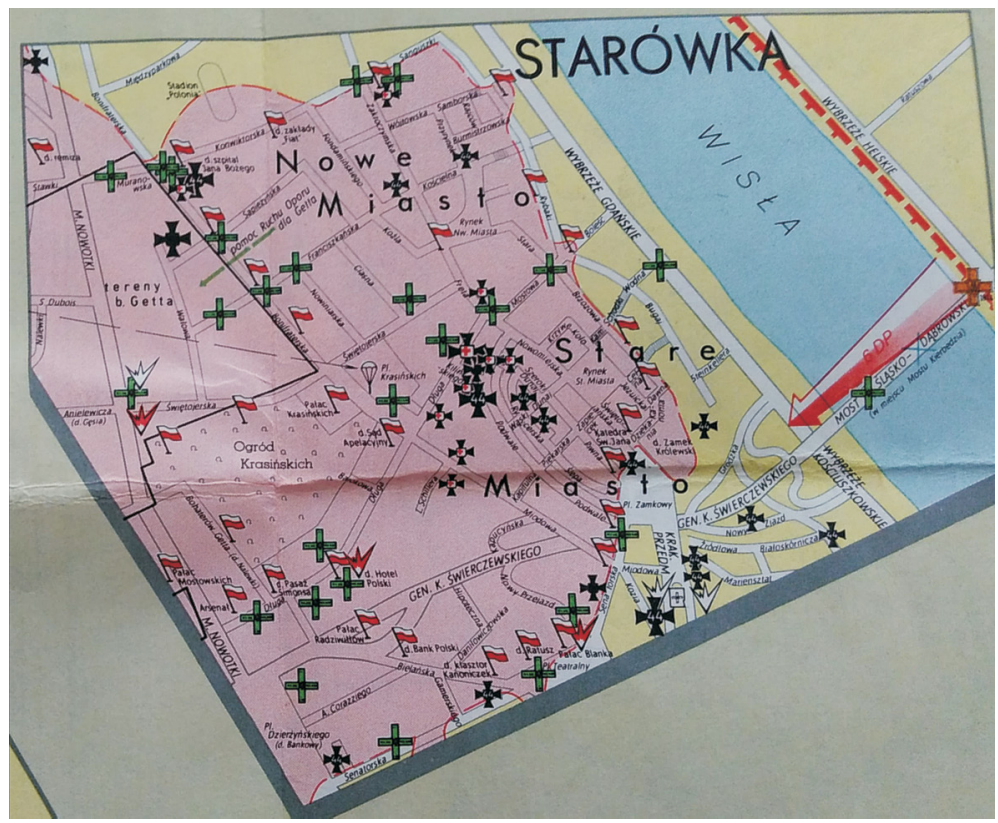

Fig. 8. The diagrams showing the number of people killed in Warsaw during the period of German occupation, dividing in to three classes: more than 1000, 100-1000 and less than 100 killed (source: J. Łopatto 1984)

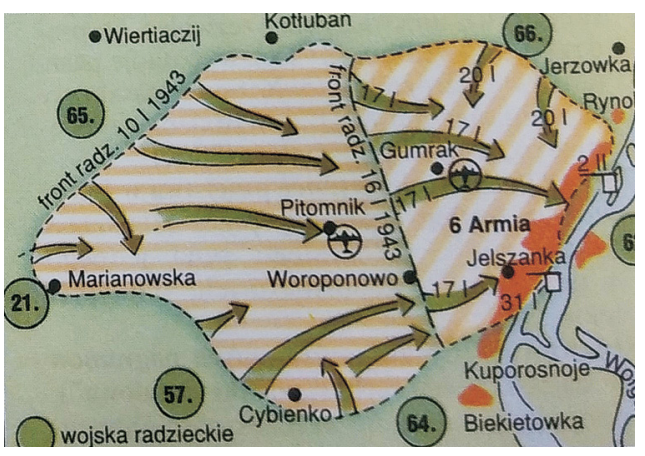

Fig. 9. A fragment of a map showing the Battle of Stalingrad 1942/1943; with the help of arrows of motion the motion of troops is presented (source: H. Kinder, W. Hilgemann 2000)

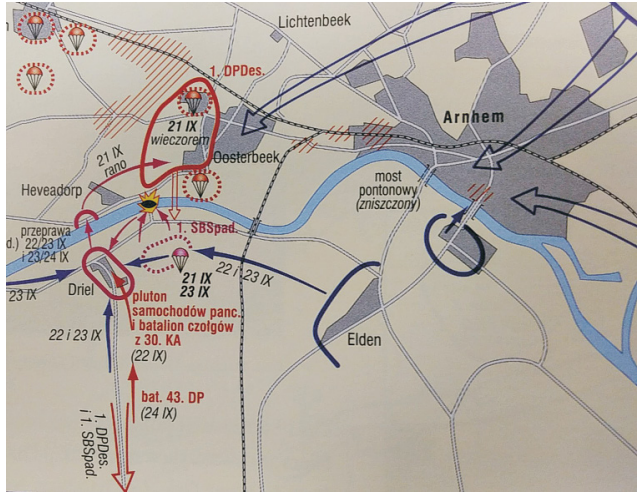

Fig. 10. The Battle at Arnhem - the use of the motion arrows to present the troops' actions (source: E. Olczak 2007) 
as well as multimedia atlases containing not only the static maps of battle courses, but also, for example, the cartographic military animations created in a very dynamic way or virtual tours showing the effects of military operations in these maps are presented in a dynamic way, e.g., using a mobile linear signature, illustrating the moving front line. The arrows of motion apply to the presentation of troops' movement direction. Changing with the passage of time, the

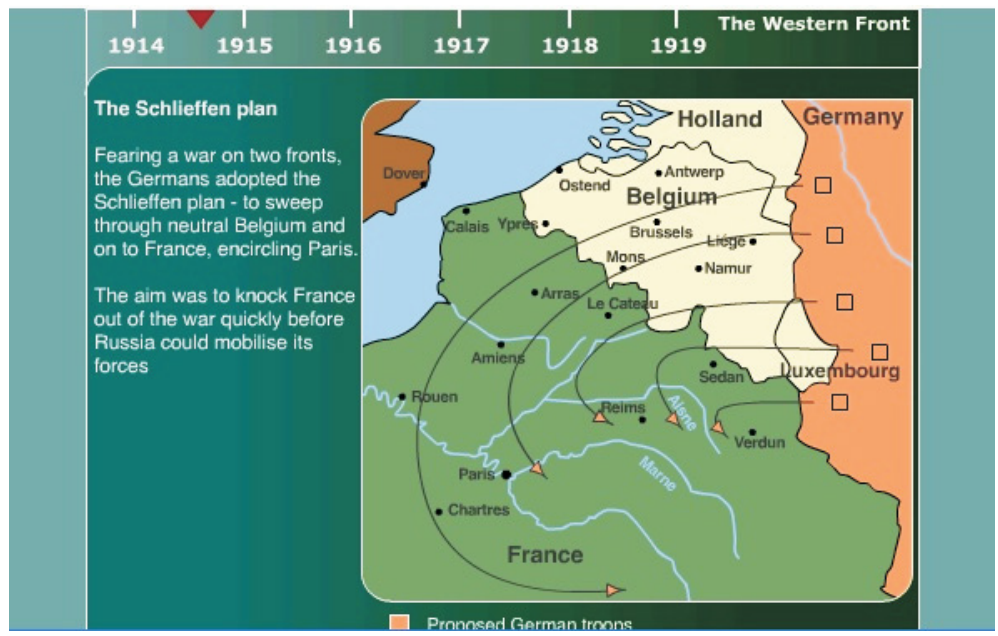

Fig. 11. Map of animated World War I (source: http://www.bbc.co.uk/history/interactive/animations/western_ front/index_embed.shtml) (access 12.06.2015)

a particular area. Geoinformation technologies also allow us to perform various types of spatial analysis. In the case of military maps they can be used to analyse a terrain, to assess the course of battle or to create the alternative scenarios of fighting course.

In this part the article presents the examples of studies related to the hostilities (often made by non-professional cartographers). The aim of the authors is not their evaluation, but the presentation of possibilities of modern techniques in the scope of making the military maps to be more attractive war cartographic elaborations.

Animated maps or cartographic animations of military operations are classified as the direct methods of presentation in order to show the dynamics of these phenomena. The geographical content of such maps is quite generalized. The main villages, rivers and borders are placed on them at the small scales. This content usually does not change during the animation. Animated maps are developed in an addition to more detailed static maps, they show in an illustrative manner the course of events. The hostilities on length of arrows shows the subsequent stages of position of troops. The introduction of width of arrows allows us to show the potential of troops. On the other methods used for such maps, "the flashing signatures" might be mentioned. They allow us to indicate the course of skirmish very clearly. Quite often the pictorial signatures are also used, simulating the explosions in the places of battles during the animation.

An important element of any animated map is its legend. It should be as simple as possible, and its contents should change as the content of map. An important element of such maps should be the timeline. Maps, showing the warfare, belong to the temporal maps, which make, that the animation time is closely connected with the real time. Accordingly, a pointer to the time axis should be closely synchronized with the course of events presented. The time scale, because of varied duration of a fighting, cannot be the same for the entire presentation. A big advantage of the animated maps is a possibility of smooth change within its displaying and enlarging. In this way we have a chance to 
show the entire battlefield and the individual skirmishes in detail. Animated maps can have interactive functions. The simplest function is the possibility to stop an action of animation, to accelerate or revert it to a certain point of time. Such maps are complemented by a voice-to-date describing the battle. Additional abilities to enhance such a presentation are archival photos or videos showing the excerpts of fighting.

The development of a cartographic animation, depicting warfare, requires to take into account the dynamic variables, such as the time of exposure, duration, frequency, order, degree of change and synchronization. Time of exposure is the time, at which begins a change of displayed image. Duration is the time, during which the image remains unchanged. A moment of hostilities, repositioning of troops and front lines have a decisive influence on the time of expo- all the details of presented events can affect the way, in which we use a variable. Synchronization in its turn refers to a temporary agreement between two or more time series.

The use of information technology also enables the creation of pseudo visualisation in three dimensions, which allow us to see the battlefield from a chosen place. It seems to be an interesting solution to use the possibilities of virtual flights over the area, on which the hostilities are conducted. This type of animations, called as non-temporal, allows to access a terrain and have a look on it from the perspective of pilots. Multimedia cartographic presentations can be enriched with photographs and panoramas presenting the direct effects of hostilities. A proprietary software allows to combine the sequences of photos into a form, that provide us with a virtual tour across the areas, which are

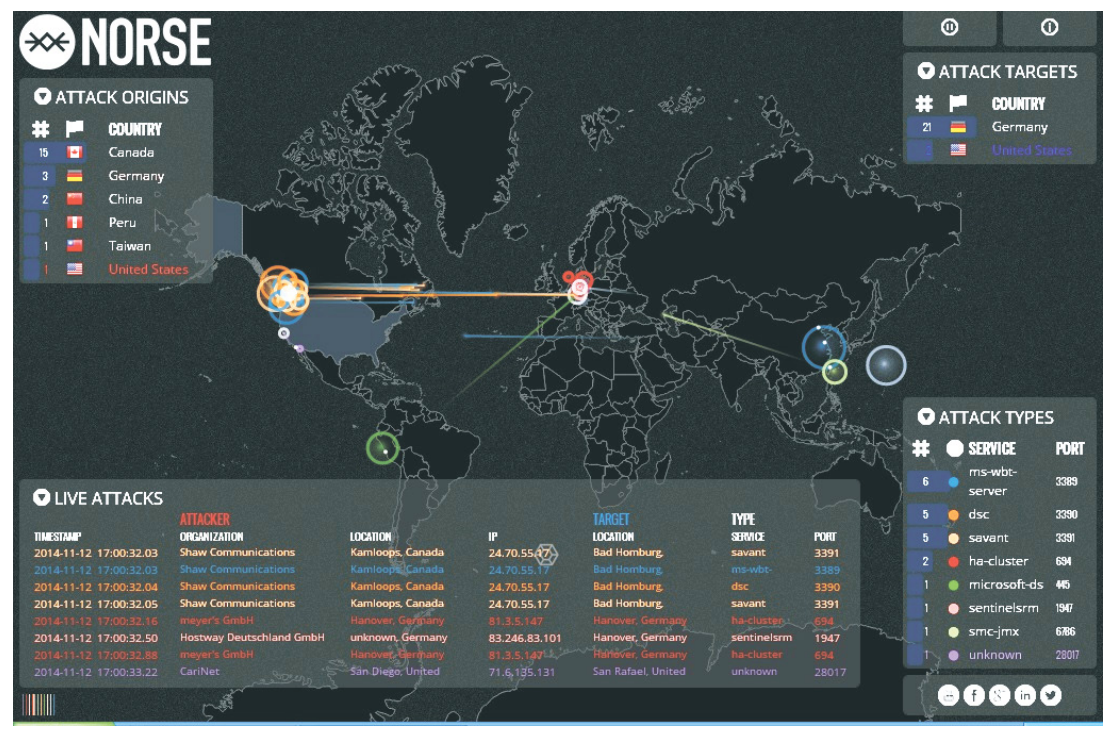

Fig. 12. An example of the cartographic animation presenting the hacker attacks (source: http://map.ipviking. $\mathrm{com} /)($ access 12.06.2015)

sure, duration and frequency. Order refers to the order of displaying the frames or scenes. A chronological order of events affects the credibility of presentation of hostilities. The degree of change determines a difference of variation amount in a given time for each sequence of frames or scenes. Duration, significance and directly affected by the hostilities. Network services such as WMS, WFS or WCS make possible the integration of data from different sources. So, we can combine archival maps and contemporary satellite images, allowing to determine the location of a specific point or place on the ground. 
An example of such a temporal animation can be found at: http://www.bbc.co.uk/history/ interactive/animations/western_front/index embed.shtml. This is a map of World War $\overline{\mathrm{I}}$, which contains all the necessary elements for this type of maps: a timeline (or an axis of time) with the index advancing together with the development of battles presented, the buttons to navigate between the animations, an animation running and a simple legend. A description of the events is placed next to the map presented. The applied methods of cartographic presentations are the method of ranges (the areas, which are exposed to the activities of the allied forces), linear signatures (the course of frontline), arrows of movement (the directions of troops' attacks) and the signatures, geometric and symbolic, indicated the places of the stationed troops. The dynamics of phenomena is present-
Warfare are not limited to the actions of military character. Wars of information or economical characters are another well-known types of actions, the aim of which is to weaken or destroy the enemy. Such actions are difficult to present on the maps. Today's war is also conducted in cyberspace. An attempt to show this type of action on the map can be found on the web-side http://map.ipviking.com/. An animated map, which is put there, presents the current situation with the hackers' attacks on Internet (fig.12). This map shows a wide range of knowledge, including the information from which country is an attack, what is its purpose and what a character it has.

Another interesting example of a multimedia map showing the warfare is a map of the American Civil War (1861-1865) published on the http://storymaps.esri.com/stories/civilwar/ (fig. 13).

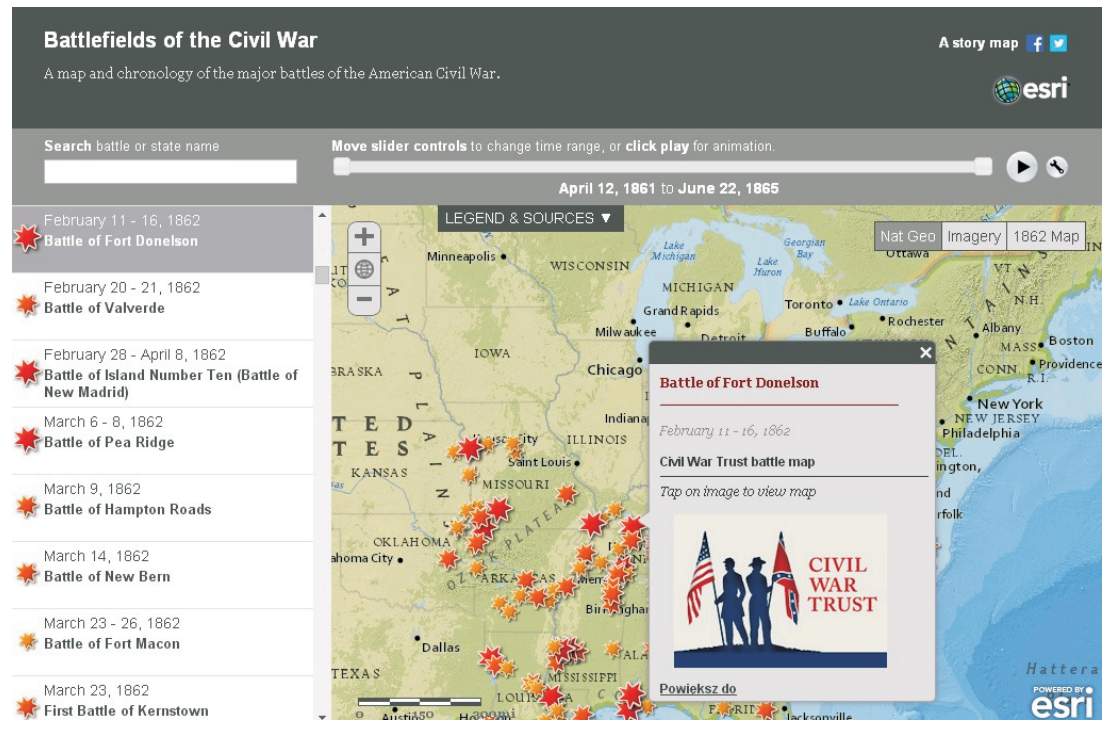

Fig. 13. Map of the Civil War (source: http://storymaps.esri.com/stories/civilwar/) (access 12.06.2015)

ed by passing signatures of points, changing frontline, which rotates its location, changing range of areas occupied by the armies and by dynamically changing vectors of troops' movement. In addition, some battle places are determined by the pattern of blinking signatures of points. This map is a part of the historic Internet service of BBC.
It is an example of the interactive map developed online by the quintessential tools ArcGis by ESRI. The locations of battles are shown by using the signatures; a click on a signature allows us to view an additional information about each battle and options to return to the pages showing the descriptions of the battle along a detailed map (fig. 14). A base map is 


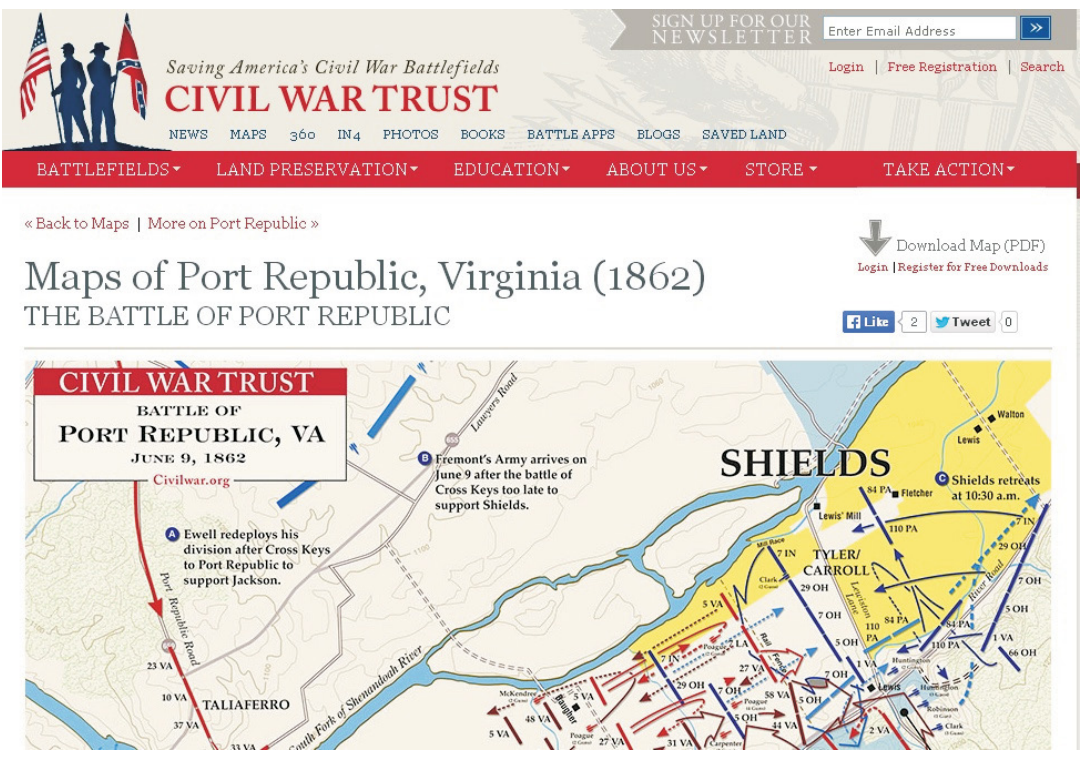

Fig. 14. The course of one of the battles of the Civil War (source: http://storymaps.esri.com/stories/civilwar/) (access 12.06.2015)

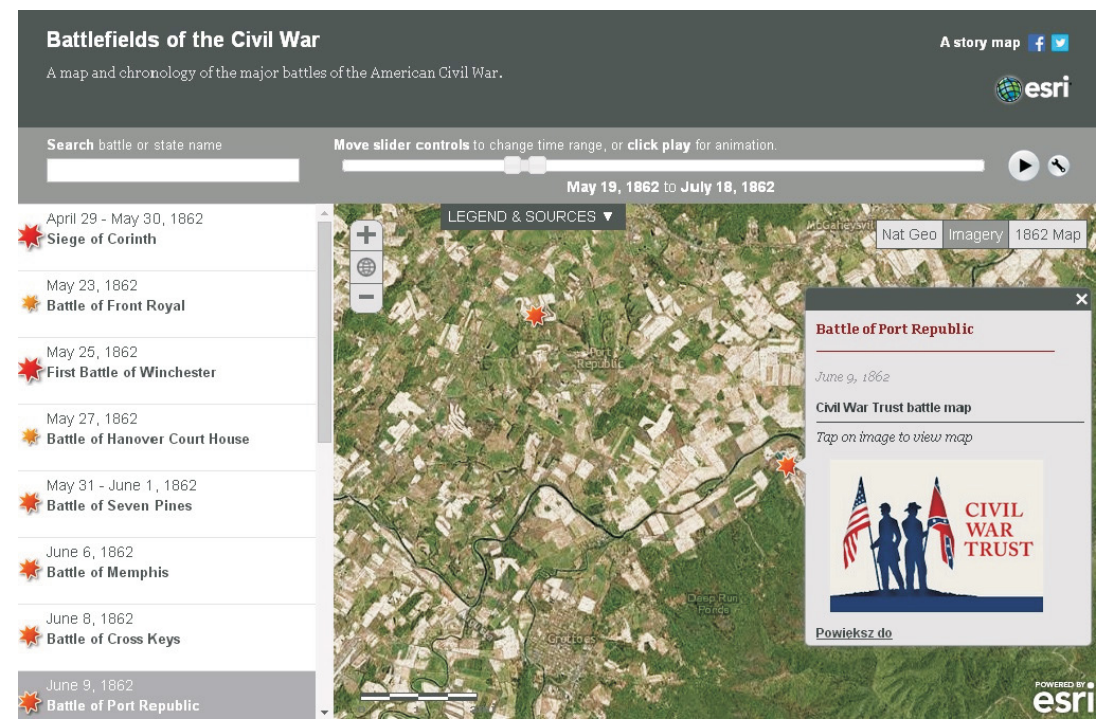

Fig. 15. The place of battle on today's satellite image (source: http://storymaps.esri.com/stories/civilwar/) (access 12.06.2015)

a contemporary map of the United States. An additional functionality of the service makes it possible to view the spot of the battle on today's satellite image (fig. 15). A user also has an ability to display the maps from 1862 as the background. The functions of animation allow us to display in a dynamic way the consecutive battles on the map. 
Another visualization techniques, other than animation ones, are used in the performance of military operations. The web-site http://www. kolor.com/virtual-tours/20140818-kolor-lewis-whyld/\#s=pano115 presented a virtual tour of Gaza Strip, showing the effects of war on its territory (fig.16). The web-site presents panoramic images of the attacks of Israeli troops. The places of attacks and the extents of the currently displayed panoramic images are shown on the map with the signatures of points. a moving user equipped with a camera is walking. This is done by free applications for mobile devices iPhone and Andorid offered by some companies, for instance, Layar and Junaio.

\section{Summary}

Maps of warfare are elaborated according to the rules developed over the years, but yet they are not deprived of various shortcomings. The article signalled the problem of elaboration of maps connected with the hostilities, de-

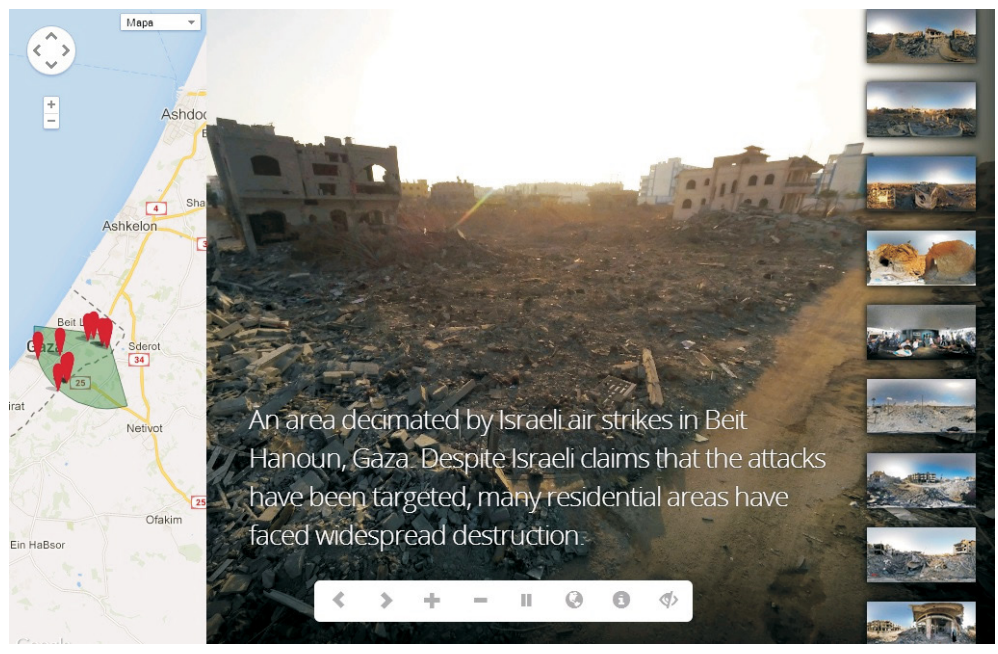

Fig. 16. A virtual tour of Gaza Strip

(source: http://www.kolor.com/virtual-tours/20140818-kolor-lewis-whyld/\#s=pano115) (access 12.06.2015)

Certain of geoinformation technologies are used to create maps for displaying on the mobile devices, such as smartphones and tablets. Built-in GPS receiver, camera and compass allow to use the so called application of augmented reality. An interesting example used for the presentation of the hostilities is the Civil War Augmented Reality Project (http://ww.historiquest.com/?p=49), which is an interactive guide to the memorial sites related to the Civil War in the United States. The applications of augmented reality (fig. 17) work on smartphones and other mobile devices, allowing for the visualization of various objects on the screen, when viewing the area by a camera pointing in a certain direction. It is possible to view 3D models of buildings and entire images, while

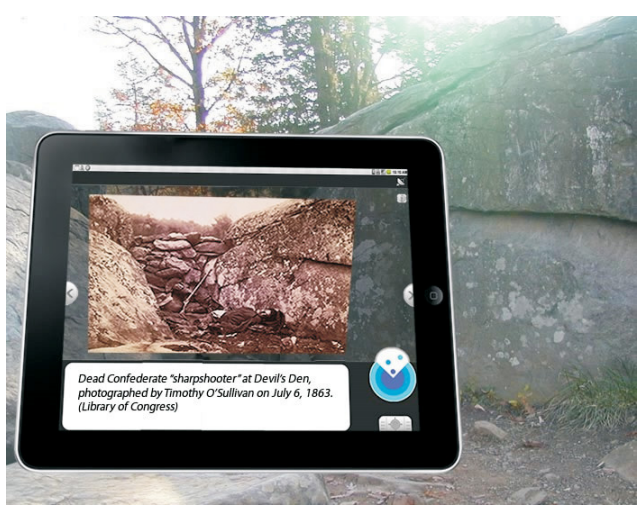

Fig. 17. Civil War Augmented Reality Project (source: http://www.historiquest.com/?p=49) (access 12.06.2015) 
scribing the methods used for the cartographic presentations and possibilities of using the modern methods of visualization, such as an augmented reality and the computer animations. The dissemination of GIS and web creators for the maps allows us to perform not only the simple maps showing the progress of the war in a static way, but also the multimedia studies enriched with the different kinds of information, accesses to the databases and animated maps. The raised issue does not cover the complexity of problems associated with the

\section{Literature}

Grygorenko W., 1984, Ewolucja poglądów na temat roli i funkcji kartografii, „Polski Przegląd Kartograficzny" T. 16, z. 2, pp. 53-57.

Ratajski L., 1989, Metodyka kartografii społeczno-gospodarczej, Wrocław: Polskie Przedsiębiorstwo Wydawnictw Kartograficznych.

Rawski T., 1984, Piechota w II wojnie światowej, Warszawa: Wydawnictwo Ministerstwa Obrony Narodowej.

\section{Maps and atlases}

Druga wojna światowa w Europie w latach 1941-1945, Warszawa: Wydawnictwo Prasa Wojskowa,1950 (wall map).

Griess T. E.: West Point Atlas For The Second World War. Europe And The Mediterranean. Avery, 1987.

Kinder H., Hilgemann W.: Atlas historii świata. T. 2, Od rewolucji francuskiej do czasów współczesnych, Warszawa: Prószyński i S-ka, 2000.

Łopatto J.: Warszawa w walce 1939-1945, Warszawa: Państwowe Przedsiębiorstwo Wydawnictw Kartograficznych, 1984.

Olczak E.: Atlas historii Polski: mapy i komentarze, Warszawa: Demart; Świat Książki, 2004.

Olczak E.: Historia Polski: atlas ilustrowany, Warszawa: Demart, 2007. development of maps presenting combat operations. These problems are mainly:

- the lack of the base maps with the content relating to the time of the events presented;

- the lack of cartographic correspondence between the contents of old and modern maps;

- the deliberate distortion of the contents of maps;

- the lack of the historical and cartographic precisions;

- the appropriate selection of the methods for the cartographic presentation.

Rawski T., Okęcki S., Stanicki Z., Tuszyński W.: Atlas wojskowo-historyczny. Walki Gwardii Ludowej i Armii Ludowej w latach 1942-1945, Warszawa: Ministerstwo Obrony Narodowej, 1953.

Swanston M.: Bitwy i kampanie. Historia w mapach, Warszawa: Bellona, 2007.

Swanston A., Swanston M.: Atlas bitew powietrznych: ilustrowana historia walk powietrznych, Poznań: Vesper, 2011.

Tschudi E.: Die Militarischen Operationen in Europa 1939-1945 / The Military Operations in Europe 1939-1945 / Les Operations Militaries en Europe 1939-1945, Bern: Kümmerly und Frey, 1964.

\section{Internet sources}

Map of animated World War I - http://www.bbc.co. uk/history/interactive/animations/western_front/ index_embed.shtml (access 06.12.2015)

Map of the Civil War - http://storymaps.esri.com/ stories/civilwar/ (access 06.12.2015)

Virtual Tour of Gaza Strip - http://www.kolor.com/virtual-tours/20140818-kolor-lewis-whyld/\#s=pano115 (access 06.12.2015)

Civil War Augmented Reality Project - http://www. historiquest.com/?p=49) (access 06.12.2015)

Map of Hacker Attack - http://map.ipviking.com/ (access 06.12.2015) 